\title{
Penentuan Area Potensi Tanah Longsor Berdasarkan Analisis Mikrotremor di Dusun Jeruk dan Sekitarnya Kecamatan Samigaluh Kabupaten Kulon Progo
}

\author{
Rusnianti Nura, Eddy Hartantyo ${ }^{b^{*}}$ \\ aProgram S2 Fisika, FMIPA, Sekip Utara Yogyakarta, 55281, Indonesia \\ bDepartemen S2 Fisika, FMIPA, UGM, Sekip Utara Yogyakarta, 55281, Indonesia \\ *Email : hartantyo@ugm.ac.id
}

(Diterima 21 Mei 2021; Disetujui 4 Desember 2021; Dipublikasikan 29 Desember 2021)

\begin{abstract}
Abstrak
Dusun Jeruk adalah salah satu daerah dengan tingkat kerawanan longsor yang tinggi. Hal ini disebabkan daerah tersebut memiliki kondisi topografi curam, tanah beragam dan curah hujan yang tinggi. Terdapat 125 kepala keluarga, 133 bangunan berupa 128 rumah penduduk, 2 masjid, 1 gereja dan 2 sekolah dasar yang dapat berdampak, sehingga pentingnya dilakukan kajian ini. Sebanyak 31 data mikrotremor tersebar pada daerah Dusun Jeruk dan sekitarnya. Pengukuran menggunakan seismometer tipe lennertz le-3d/20s selama 45 menit dengan frekuensi sampling $100 \mathrm{~Hz}$. Data mikrotremor diolah menggunakan software geopsy dengan metode Horizontal to Vertical Spatial Ratio (HVSR) dan pembobotan pada setiap parameter dengan metode statistik Analytical Hierarchy Process (AHP) dalam penentuan area potensi longsor. Hasil yang diperoleh menunjukkan bahwa persebaran nilai frekuensi dominan (fo) sebesar 3,3 Hz-18,05 Hz, amplifikasi $(A o)$ berkisar antara 1,2-7,06, indeks kerentanan seismik $(K g)$ antara $0,12-7,67 \mathrm{~s}^{2} / \mathrm{cm}$, ketebalan lapisan sedimen $(h)$ berkisar antara 7,67-69,42 meter, GSS berkisar antara 1,2 $\times 10^{-5}-6,8 \times 10^{-4}$ dan nilai PGA berkisar antara 93,20-215,95 gal. Berdasarkan perhitungan pembobotan dengan metode statistik AHP, daerah yang mempunyai potensi longsor tertinggi adalah Dusun Jeruk, Dusun Ngelebengan, Dusun Kalipak, Dusun Kemiriombo dan Dusun Manggis, sedangkan daerah yang tidak mempunyai potensi longsor tinggi adalah Dusun Srimulyo dan Dusun Pelet.
\end{abstract}

Kata kunci: Analytical Processing Hierarchy , Mikrotremor, Potensi, Tanah longsor.

\section{Pendahuluan}

Fenomena pergerakan massa tanah atau batuan di sepanjang lereng akibat perubahan kestabilan lereng merupakan fenomena kejadian tanah longsor. Salah satu gangguan terhadap ketidakstabilan lereng adalah adanya gempa bumi yang memicu pergerakan massa tanah, mengubah kondisi lereng yang rawan atau siap bergerak menjadi kondisi kritis dan akhirnya bergerak [1]. Daerah yang sering terjadinya tanah longsor adalah Kecamatan Samigaluh, Kulon Progo.

Wilayah Kecamatan Samigaluh, Kulon Progo terkhusus pada Dusun Jeruk dan sekitarnya diperkirakan memiliki potensi bahaya longsor yang tinggi. Hal ini dikarenakan memiliki kondisi topografi, geologi, penggunaan lahan , curah hujan dan tanah yang beragam. Kondisi beragam inilah yang dapat menyebabkan tingkat kerentanan longsor tinggi di beberapa wilayah. Secara topografis, sebagian besar berupa perbukitan tinggi dengan kemiringan lereng yang sedang hingga curam dan ketinggian berkisar antara 500 sampai 800 meter di atas permukaan air laut [2]. Tersusun dari batuan andesit, konglomerat, breksi andesit, tuf lapili, batu pasir, batu gamping dan aglomerat [3] yang sedang lapuk di bagian luar menjadi tanah, sehingga potensial terjadinya tingkat pelepasan batuan sangat tinggi. Penggunaan lahan juga berbeda seperti perkebunan, pemukiman, dan sawah. Selain itu, Kecamatan Samigaluh memiliki curah hujan yang paling tinggi di antara kecamatan lainnya. Rata-rata setiap tahun mencapai $2.150 \mathrm{~mm}$ dengan hari hujan 106 hari setiap tahun atau 9 hari dalam sebulan dengan curah hujan paling tinggi di bulan November dan paling sedikit di bulan Agustus [4]. Kondisi ini mengakibatkan banyaknya peristiwa tanah longsor yang terjadi. Kejadian tanah longsor dalam rentang tahun 2010 hingga 2020 tercatat sebanyak 396 kejadian yang mengakibatkan 194 rumah rusak, 46 terluka dan 7 meninggal [5].

Kerusakan yang akan ditimbulkan akibat kejadian longsor bukan hanya kerusakan langsung seperti kerusakan kantor-kantor, fasilitas umum, hilangnya tanah pertanian dan perkebunan serta korban jiwa, namun kerusakan secara tidak 
langsung melumpuhkan pembangunan daerah dan kegiatan ekonomi. Salah satunya pada sektor wisata yaitu pada 2 lokasi wisata yang dekat daerah penelitian yakni wisata Kedung Sowo dan Goa Banyu Semurup dan terdapat 125 kepala keluarga serta 133 bangunan berupa 128 rumah penduduk, 2 masjid, 1 gereja dan 2 sekolah dasar yang dapat berdampak apabila terjadinya tanah longsor. Peristiwa tanah longsor pernah terjadi pada tanggal 1 Maret 2017 di Dusun Jeruk yang mengakibatkan terjadinya rekahan dan amblesan tanah sepanjang 700 meter yang mengancam lahan pertanian sekitar 1 hektar dan 8 rumah warga [5], sehingga dengan kejadian ini pentingnya dilakukan mitigasi bencana.

Pentingnya upaya mitigasi perlu dilakukan untuk meminimalkan terjadinya tanah longsor, sehingga dampak yang ditimbulkan dapat teratasi. Tindakan mitigasi bencana dapat dilakukan dengan mengidentifikasi daerah berpotensi longsor berdasarkan karakteristik tanah. Identifikasi dilakukan dengan metode geofisika, yaitu metode mikrotremor dengan menggunakan teknik Horizontal to Vertical Spectral Ratio (HVSR) dan pemetaan dengan metode pembobotan statistik Analitycal Hierarchy Process (AHP) untuk menentukan area yang berpotensi mengalami tanah longsor.

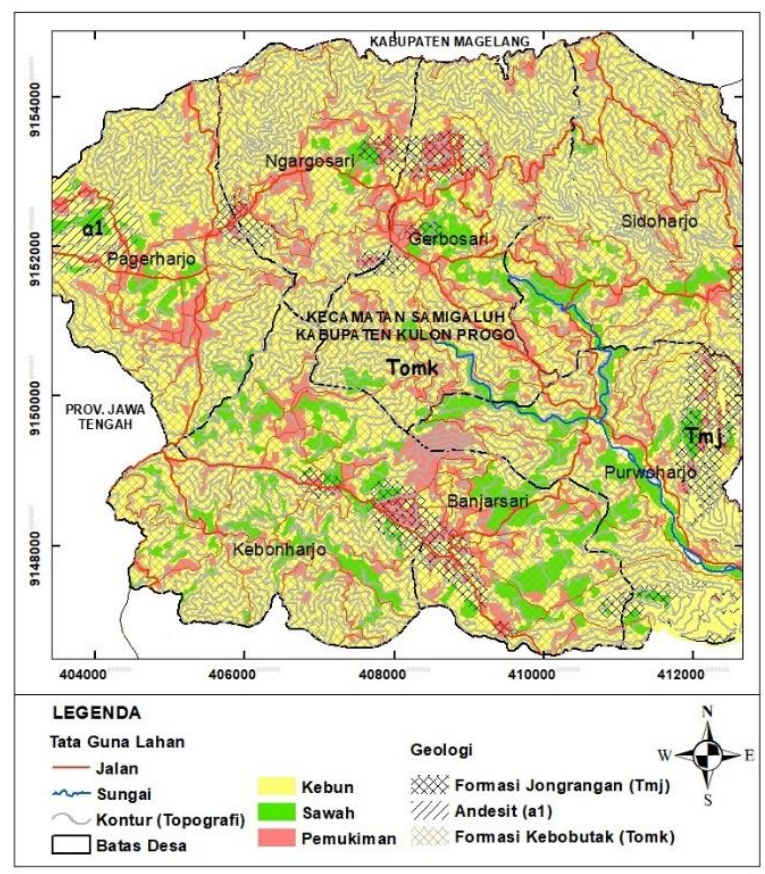

Gambar 1. Peta kondisi umum kecamatan Samigaluh meliputi topografi, geologi dan tata guna lahan.

\section{Metodologi}

Pengambilan data mikrotremor menggunakan seismometer tipe lennartz Le-3d/20s sebanyak 31 titik pengukuran selama 7 hari pada tanggal 24-31 Agustus 2020. Lokasi pengambilan data meliputi dua perbukitan terletak pada koordinat geografis $7^{\circ} 41^{\prime} 17,48^{\prime \prime}-7^{\circ} 41^{\prime} 7,47^{\prime \prime}$ LS dan $110^{\circ} 9^{\prime} 6,3^{\prime \prime}$ $110^{\circ} 10^{\prime} 24,1^{\prime \prime} \mathrm{BT}$ yang mencakup lima dusun yaitu Jeruk, Manggis, Kalipak, Kemiriombo, Sarimulyo, Petet dan Ngelebengan. Setiap titik dilakukan pengambilan data selama 45-50 menit dengan frekuensi sampling $100 \mathrm{~Hz}$ dan target frekuensi 0$20 \mathrm{~Hz}$.

Data mikrotremor diolah menggunakan software Geopsy dengan metode Horizontal to Vertical Spatial Ratio (HVSR). Pemilihan lebar window sebesar 25 sekon, koreksi smoothing Konno Ohmaci dengan 40 bandwith dan taper fungsi cosinus $5 \%$. Proses perhitungan frekuensi menggunakan fast fourier transform (FFT). Hasil proses data diperoleh kurva HVSR untuk setiap titik pengukuran. Contoh data hasil proses ditampilkan pada Gambar 2.

Terdapat tiga bentuk kurva HVSR dalam penelitian ini berdasarkan kriteria SESAME [6], yaitu clearpeak, two peak, broadband (noise rendah) dan flat (sangat noise). Dalam prosesnya, kurva HVSR yang berbentuk two peak, dipilih nilai amplifikasi yang lebih tinggi dari dua frekuemsi puncaknya. Sedangkan data yang sangat noise yang berbentuk flat tidak digunakan dalam penelitian ini.

Kurva HVSR yang diperoleh menghasilkan nilai frekuensi dominan (fo) dan nilai amplifikasi $(A o)$ dari masing-masing titik pengukuran. Nilai frekuensi dominan (fo) dan amplifikasi (Ao) kemudian digunakan sebagai parameter awal untuk menghitung parameter lainnya. Parameter lainnya meliputi indeks kerentanan seismik $(\mathrm{kg})$, ketebalan lapisan sedimen $(h)$, percepatan tanah maksimum (PGA), dan regangan geser tanah (GSS).

Perhitungan Indeks kerentanan seismik (Kg) berdasarkan perbandingan kuadrat dari nilai amplifikasi $(A o)$ dengan frekuensi dominan $(f o) \mathrm{di}$ daerah penelitian dituliskan pada persamaan (1) [7]:

$$
K g=\frac{A o^{2}}{f o}
$$

Ketebalan lapisan sedimen dihitung dari perbandingan nilai kecepatan gelombang geser (Vs) dengan frekuensi dominan pada persamaan (2) [8]: 


$$
h=\frac{V_{S}}{4 f_{0}}
$$

Data kecepatan gelombang geser $(V s)$ berasal dari 30 meter bagian atas lapisan lunak (Vs30) pada setiap titik pengukuran yang diperoleh dari laman United States Geological Service (USGS) dan nilai frekuensi dominan $(f o$ ) dari hasil pengukuran mikrotremor di lapangan.

Perhitungan peak ground acceleration (PGA) di permukaan menggunakan persamaan Kanai [9] dengan parameter gempa bumi yang memiliki magnitudo terbesar dan jarak episentrum terdekat dengan lokasi penelitian. Parameter gempa bumi yang digunakan, yaitu gempa yang terjadi pada 27 Mei 2006, kekuatan 6,3 skala richter, dan kedalaman $10 \mathrm{~km}$. Secara matematis perhitungan peak ground acceleration (PGA) [9] dituliskan pada persamaan (3)

$\alpha_{\mathrm{a}}=\frac{5}{\sqrt{\mathrm{T}_{\mathrm{o}}}} 10^{0.61 \mathrm{M}_{\mathrm{W}}-1.66 \log _{10} \mathrm{R}-\frac{3.60}{\mathrm{R}} \log _{10} \mathrm{R}+0.167-\frac{1.83}{\mathrm{R}}}$

dengan $\alpha_{\mathrm{a}}$ adalah PGA di lapisan tanah permukaan dalam gal atau $\mathrm{cm} / \mathrm{s}^{2}$ atau $0.01 \mathrm{~cm} / \mathrm{s}^{2}, \mathrm{~T}_{\mathrm{o}}$ periode dominan tanah di titik pengukuran dalam sekon, $M$ magnitudo gempa dalam SR dan R jarak hiposenter dalam $\mathrm{km}$.

Ground shear strain dihitung dengan mengalikan antara indeks kerentanan seismik (Kg) dengan peak ground acceleration (PGA) di batuan dasar. Peak ground acceleration (PGA) di batuan dasar dihitung menggunakan metode Mc.Guirre [10]. Secara matematis perhitungan dituliskan pada persamaan (4):

$$
\alpha_{\mathrm{b}}=(472.3) 10^{0.27 \mathrm{M}}(\mathrm{R}+25)^{-1.30}
$$

dengan $\alpha_{\mathrm{b}}$ adalah PGA di batuan dasar dalam gal atau $\mathrm{cm} / \mathrm{s}^{2}$ atau $0.01 \mathrm{~cm} / \mathrm{s}^{2}, \mathrm{M}$ magnitudo gempa dalam SR dan R jarak hiposenter dalam km. Dengan demikian ground shear strain $(\gamma)$ dituliskan sebagai persamaan (5) [8] :

$$
\gamma=\mathrm{k}_{\mathrm{g}} \times 10^{-6} \times \alpha_{\mathrm{b}}
$$

Hasil nilai semua parameter analisis diolah menjadi peta persebaran atau biasa disebut contouring dengan aplikasi Surfer dan ArcGis. Nilai Parameter pada setiap titik pengukuran selanjutnya diolah menggunakan metode pembobotan statistik Analytical Hierarchy Process (AHP) dalam penentuan area potensi longsor.

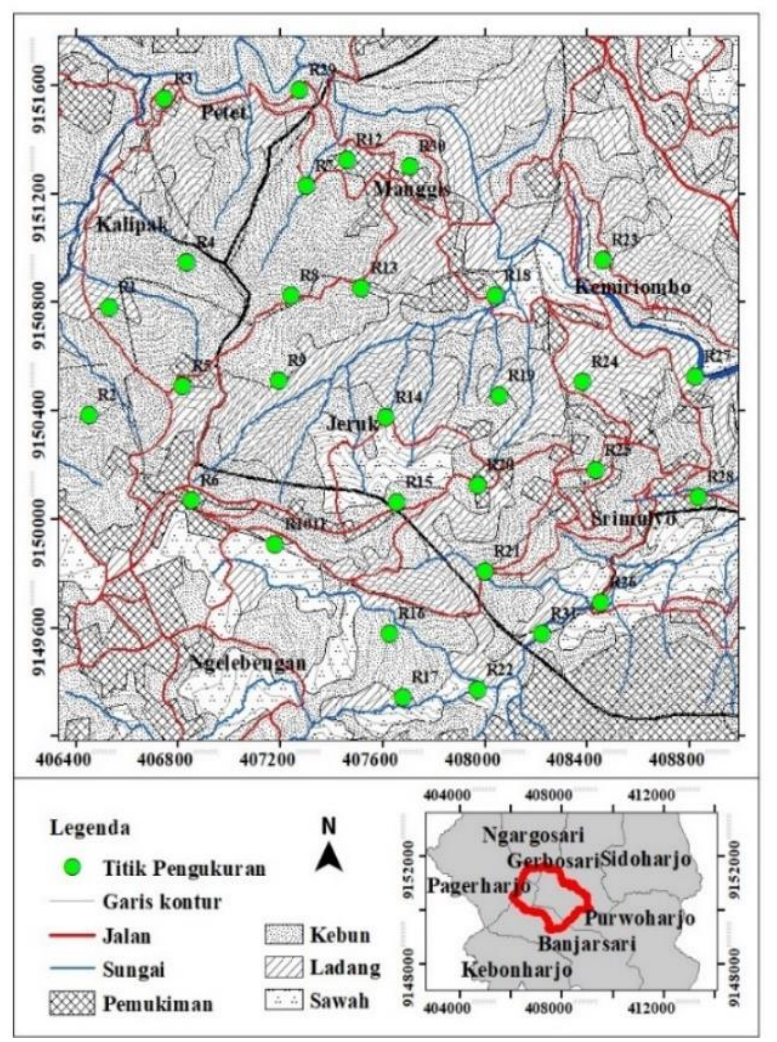

Gambar 2. Lokasi daerah penelitian (kotak merah) dan persebaran titik pengukuran (bulat hijau).

\section{Hasil dan Pembahasan}

Klasifikasi kriteria bentuk kurva HVSR yang dihasilkan, diperoleh 11 titik data berupa clear peak, 9 titik data two peak, dan 10 titik data broadband, sehingga terdapat 30 data yang valid dan dapat digunakan dalam penelitian ini. Akan tetapi, terdapat 1 titik data tidak digunakan sebab memiliki noise yang tinggi (lihat Tabel 1).

\begin{tabular}{|c|c|c|c|}
\hline No & Kriteria & $\begin{array}{c}\text { Titik } \\
\text { Pengukuran } \\
\end{array}$ & Jumlah \\
\hline 1 & $\begin{array}{l}\text { Clear } \\
\text { peak }\end{array}$ & $\begin{array}{l}\text { R1, R3, R7, R9, } \\
\text { R1011, R12, } \\
\text { R13, R14, R19, } \\
\text { R27, R28 }\end{array}$ & 11 \\
\hline 2 & $\begin{array}{l}\text { Two } \\
\text { peak }\end{array}$ & $\begin{array}{l}\text { R4, R5, R6, R8, } \\
\text { R16, R17, R20, } \\
\text { R21, R31 }\end{array}$ & 9 \\
\hline 3 & $\begin{array}{l}\text { Brod } \\
\text { band }\end{array}$ & $\begin{array}{l}\text { R2, R25, R18, } \\
\text { R22, R23, R24, } \\
\text { R25, R26, R29, } \\
\text { R30 }\end{array}$ & 10 \\
\hline 4 & flat & R32 & 1 \\
\hline
\end{tabular}

Tabel 1. Klasifikasi kriteria kurva HVSR pada setiap titik pengukuran 


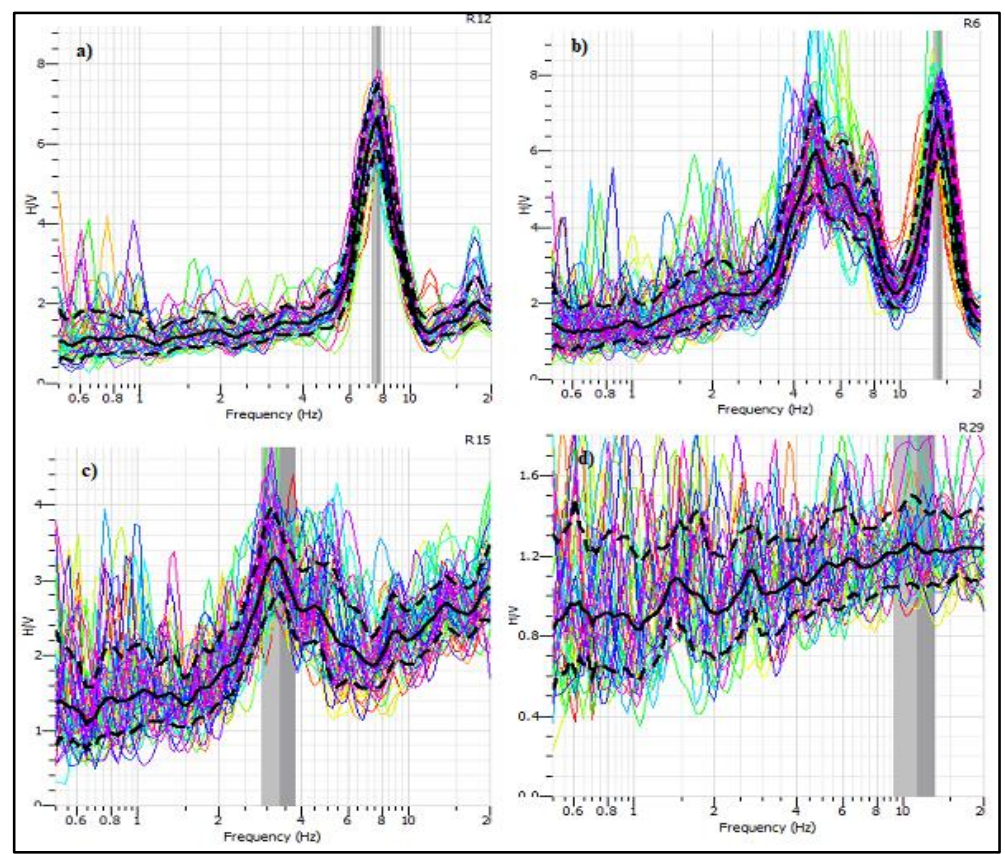

Gambar 3. Contoh hasil data proses berdasarkan kroteria oleh SESAME [6]. a) clearpeak, b) two peak, c) broadband dan d) flat.

\subsection{Frekuensi dominan (fo)}

Berdasarkan data yang diperoleh, nilai frekuensi dominan $(f o$ ) daerah penelitian memiliki nilai antara $3.36 \mathrm{~Hz}-18.05 \mathrm{~Hz}$ seperti yang ditampilkan pada Gambar 3.

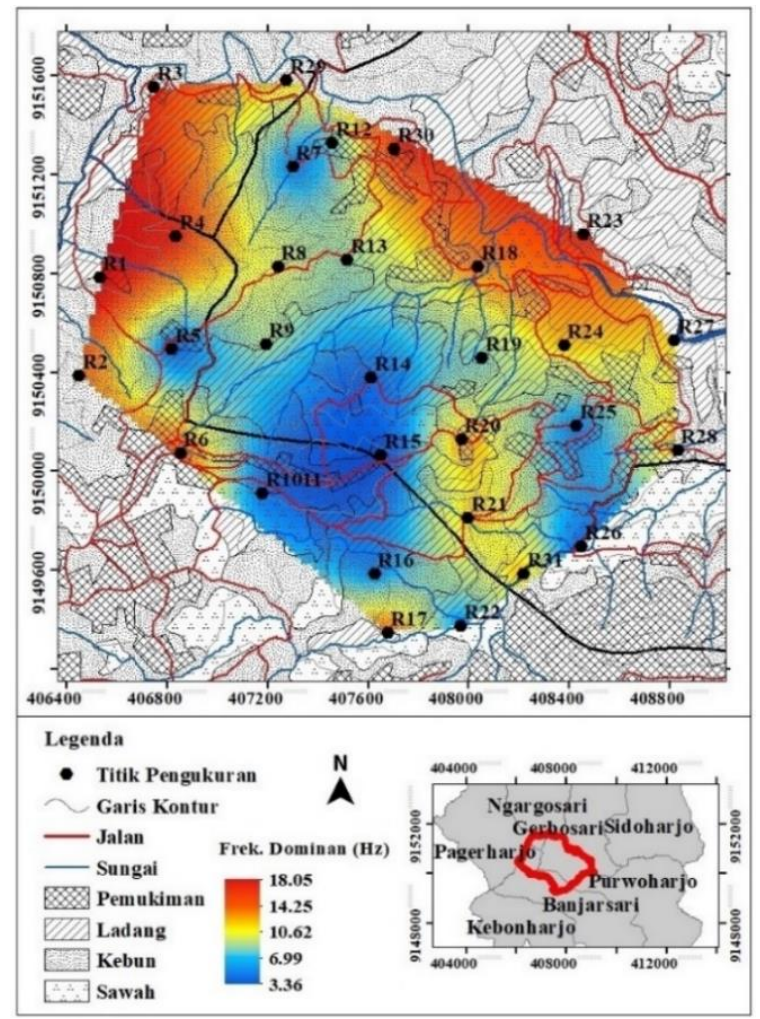

Gambar 4. Peta sebaran nilai frekuensi dominan (fo) pada setiap titik pengukuran. Frekuensi dominan (fo) rendah (biru), sedang (kuning), dan tinggi (merah).
Merujuk pada klasifikasi tanah oleh Kanai [9], daerah penelitian yang termasuk zona rendah memiliki frekuensi dominan rendah termasuk ke dalam klasifikasi tanah jenis I, yaitu pada daerah Dusun Jeruk (R5, R14, R15), Dusun Kemiriombo (R25), Dusun Srimulyo (R26), dan Dusun Ngelebengan (R1011, R16, R22) dimungkinkan memiliki ketebalan sedimen permukaan yang tebal. Sedangkan zona tinggi yaitu zona yang memiliki nilai frekuensi dominan tinggi, termasuk dalam Dusun Jeruk (R6), Dusun Manggis (R30), Dusun Kemiriombo (R23), Dusun Kalipak (R1, R2, R4), dan Dusun Petet (R3) masuk dalam klasifikasi tanah jenis II yang memiliki ketebalan permukaan sedimen yang tipis dan didominasi batuan keras.

\subsection{Amplifikasi $(A o)$}

Nilai amplifikasi $(A o)$ daerah penelitian memiliki nilai antara $3.36 \mathrm{~Hz}-18.05 \mathrm{~Hz}$ yang ditampilkan pada Gambar 4. Amplifikasi (Ao) berkaitan dengan penguatan gelombang atau respon lapisan permukaan terhadap guncangan [1]. Daerah yang berada pada zona amplifikasi tinggi, jika terjadi getaran dimungkinkan dapat terjadi potensi goncangan atau pergerakan tanah yang kuat. Merujuk pada klasifikasi nilai faktor amplifikasi [10], daerah penelitian yang termasuk zona rendah pada daerah Dusun Jeruk (R5, R18, R21), Dusun manggis (R8), Dusun Kemiriombo 
(R23, R25), Dusun Srimulyo (R26), Dusun Kalipak (R2), Dusun Petet (R29), dan Dusun Ngelebengan (R16, R22). Sedangkan zona tinggi yaitu zona yang memiliki nilai amplifikasi tinggi, termasuk dalam Dusun Jeruk (R6, R13), Dusun Manggis (R12), Dusun Petet (R3), dan Dusun Ngelebengan (R1011).

\subsection{Indeks kerentanan seismik $(\mathrm{Kg})$}

Nilai indeks kerentanan seismik $(\mathrm{Kg})$ di daerah penelitian memiliki nilai antara $0.13 \mathrm{~cm} / \mathrm{s}^{2}$ - $7.06 \mathrm{~cm} / \mathrm{s}^{2}$ yang ditampilkan pada Gambar 5 . Daerah penelitian memiliki nilai yang cukup bervariasi, daerah yang termasuk zona rendah pada daerah Dusun Jeruk (R5, R18, R19, R20, R21), Dusun manggis (R8, R30), Dusun Kemiriombo (R23, R24, R25, R27), Dusun Kalipak (R1, R2, R4), Dusun Petet (R29), dan Dusun Ngelebengan (R16, R17, R22) dimungkinkan daerah ini tahan terhadap goncangan. Sedangkan zona sedang hingga tinggi yaitu zona yang memiliki nilai indeks kerentanan $(\mathrm{Kg})$ tinggi yaitu Dusun Jeruk (R14) dan Dusun Ngelebengan (R1011) rentan terkena dampak akibat goncangan.

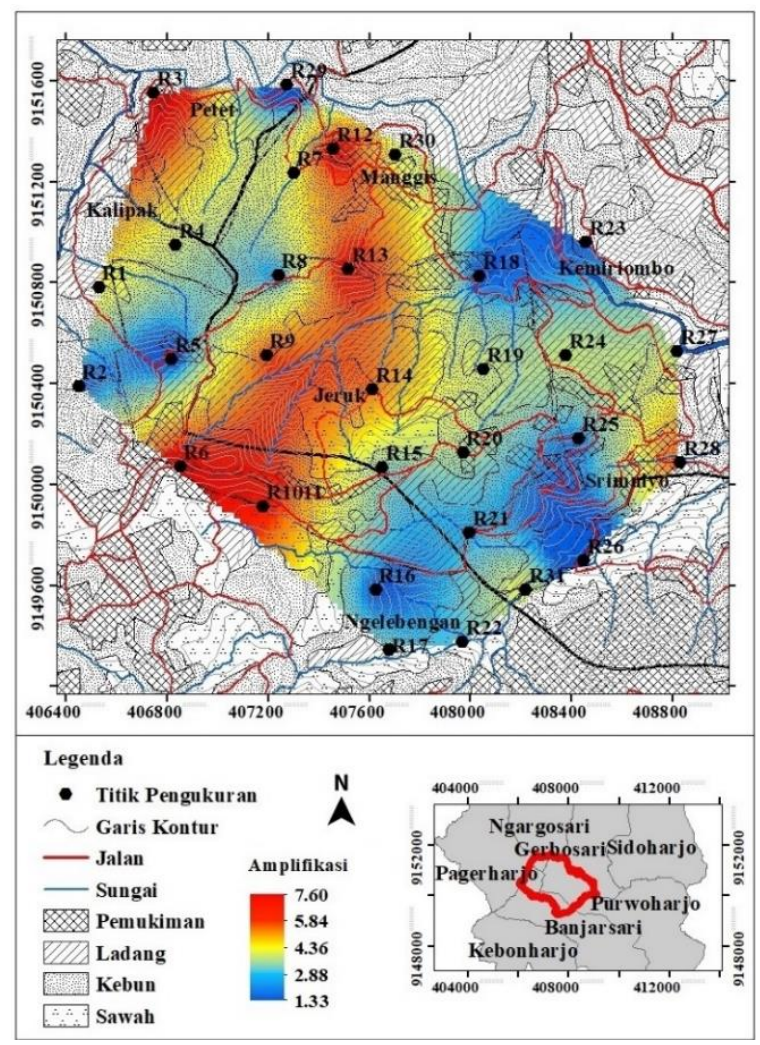

Gambar 4. Peta sebaran nilai amplifikasi (fo) pada setiap titik pengukuran. Amplifikasi $(A o)$ rendah (biru), sedang (kuning), dan tinggi (merah).

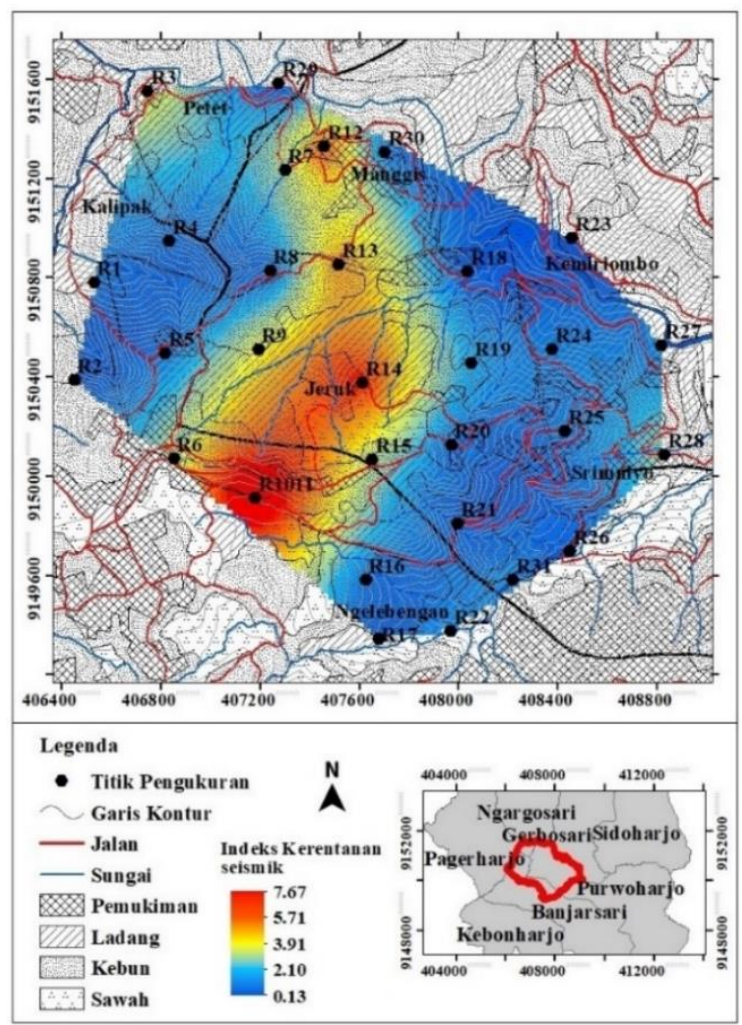

Gambar 5. Peta sebaran nilai indeks kerentanan seismik $(\mathrm{Kg})$ pada setiap titik pengukuran. Indeks kerentanan seismik $(K g)$ rendah (biru), sedang (kuning), dan tinggi (merah).

\subsection{Ketebalan lapisan sedimen $(h)$}

Ketebalan lapisan sedimen di daerah penelitian memiliki nilai antara 7,6-69,4 meter seperti yang ditampilkan pada Gambar 6 . Berdasarkan data yang diperoleh, titik R15 merupakan titik sedimen yang paling tebal. Berdasarkan pengamatan di lapangan, terdapat tanah yang lapuk pada titik R15. Hal itu terlihat dari tanah yang berwarna coklat kemerahan dan sangat gembur di sekitar lokasi.. Ditinjau dari klasifikasi ketebalan sedimen [10], daerah penelitian memiliki lapisan sedimen yang tipis hingga tebal. Sementara itu, batuan dasar (bedrock) di daerah penelitian memiliki elevasi antara 300,5-643,6 meter.

Elevasi batuan dasar dapat diketahui dengan mengurangi elevasi tiap titik pengukuran dengan ketebalan lapisan sedimen $(h)$ ditampilkan pada Gambar 7. Elevasi batuan dasar menunjukkan adanya bidang gelincir yang cukup curam antara lapisan batuan dasar dengan lapisan sedimen yang berada di atasnya sehingga memungkinkan terjadinya pergerakan tanah. Berdasarkan arah bidang gelincir dan arah kemiringan lereng (topografi) yaitu pada titik R15, arah longsoran diperkirakan mengarah ke timur laut. 


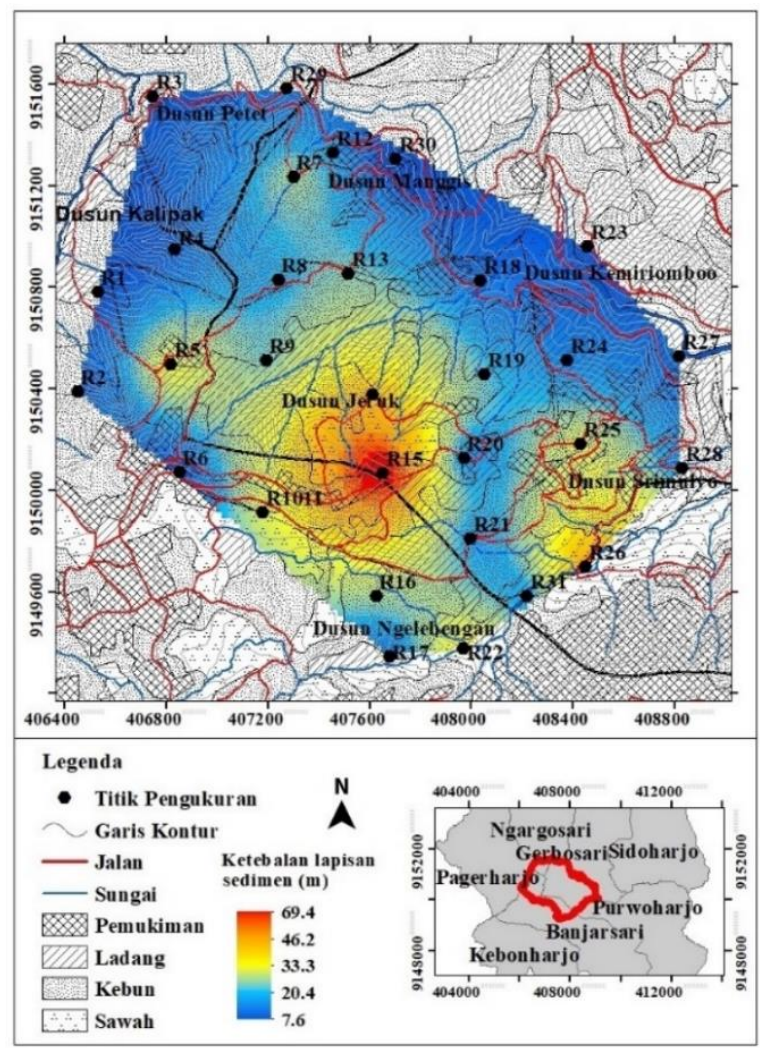

Gambar 6. Peta sebaran nilai ketebalan lapisan sedimen $(h)$ pada setiap titik pengukuran. Ketebalan lapisan sedimen $(h)$ tipis (biru), sedang (kuning), dan tebal (merah).

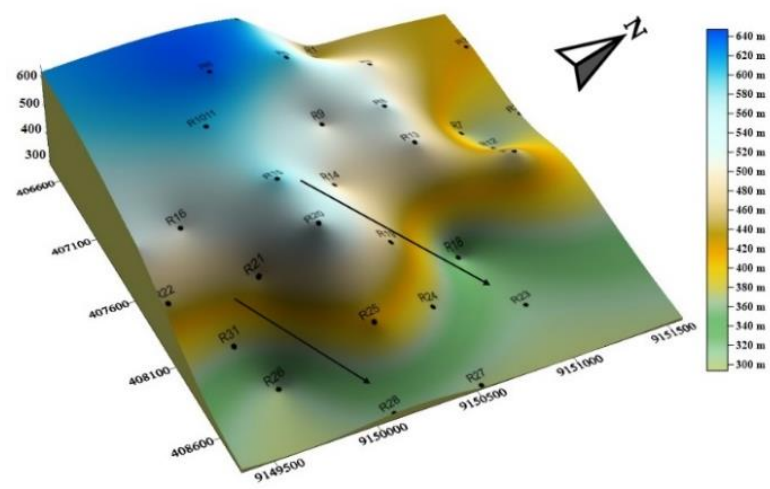

Gambar 7. Elevasi batuan dasar (bedrock) 3D dilihat dari sisi tenggara-barat laut dan arah panah menunjukkan arah longsoran ke timur laut.

\subsection{Peak Ground Acceleration (PGA)}

Nilai peak ground acceleration (PGA) permukaan di daerah penelitian berkisar antara 93,2 gal - 215,9 gal yang ditampilkan pada gambar 7. Daerah penelitian didominasi memiliki nilai PGA sedang hingga tinggi.

Merujuk pada skala intensitas gempa bumi [11]. Kerusakan yang akan terjadi pada daerah penelitian apabila terjadi gempa bumi yang berepisentrum di sekitar gempa Yogyakarta pada masa akan datang yakni kerusakan ringan pada daerah Dusun Jeruk (R6, R5, R14, R15, R9, R13, R19), Dusun Manggis (R30, R27, R28), Dusun Kemiriombo (R25), Dusun Srimulyo (R26), Dusun Ngelebengan (R16, R1011) dan kerusakan sedang pada daerah Dusun Jeruk (R18, R20, R21), Dusun Manggis (R30, R27, R28), Dusun Kemiriombo (R23, R24, R27), Dusun Srimulyo (R28, R31), Dusun Kalipak (R1, R2, R4), Dusun Petet (R3, R29), dan Dusun Ngelebengan (R17, R22).

\subsection{Ground Shear-Strain (GSS)}

Nilai ground shear strain (GSS) menggambarkan kemampuan permukaan tanah untuk meregang maksimum jika terjadi gempabumi. Pada daerah penelitian nilai ground shear strain (GSS) diperoleh nilai berkisar antara $1,2 \times 10^{-5}-6,8 \times 10^{-4}$ yang ditampilkan pada Gambar 8. Daerah dengan nilai ground shear strain (GSS) yang tinggi cenderung meregang atau bergeser sehingga terjadi deformasi seperti longsoran [12]. Jika dilihat hubungan antara nilai ground shear strain (GSS) dan sifat dinamika menurut Ishihara [12], daerah penelitian memiliki dinamika tanah yang elastis-plastis.

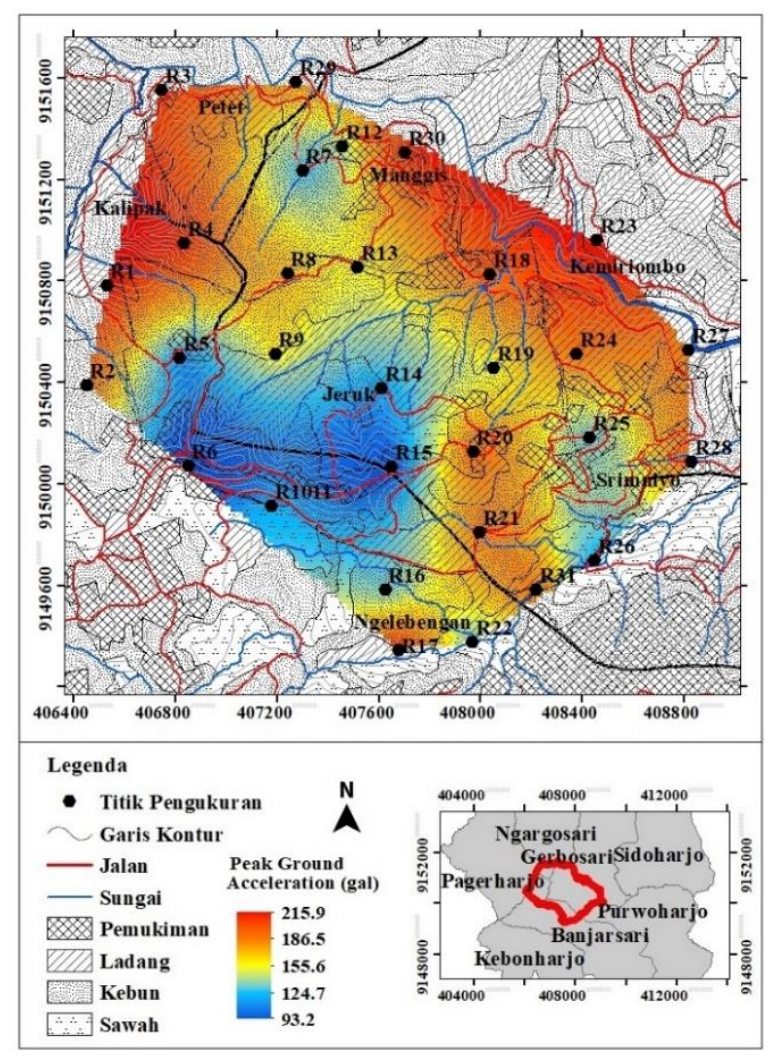

Gambar 8. Peta sebaran nilai peak ground acceleration (PGA) di permukaan pada setiap titik pengukuran. Nilai PGA rendah (biru), sedang (kuning), dan tinggi (merah). 


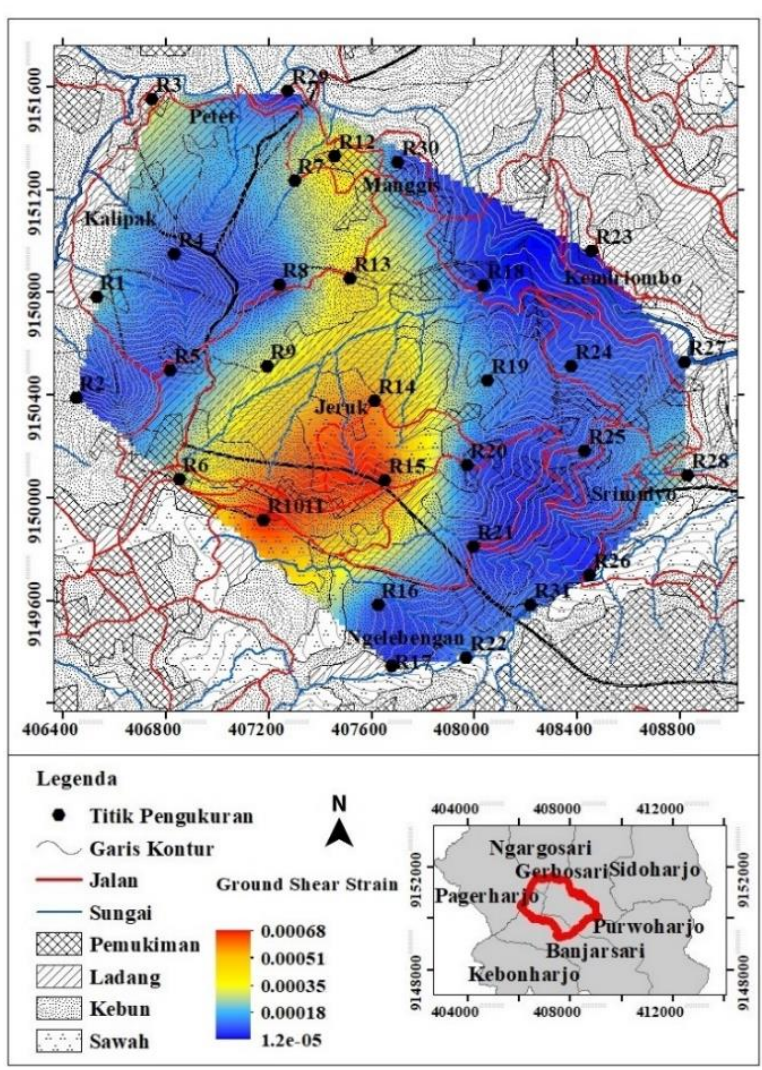

Gambar 9. Peta sebaran nilai ground shear strain (GSS) pada setiap titik pengukuran. Ground shear strain (GSS) rendah (biru), sedang (kuning), dan tinggi (merah).

Daerah yang termasuk elastis yakni Dusun Jeruk (R5, R18, R20, R21), Dusun Manggis (R8), Dusun Kemiriombo (R23), Dusun Srimulyo (R26), Dusun Kalipak (R2, R4), Dusun Petet (R29), dan Dusun Ngelebengan (R16, R17) yang dapat terjadi berupa gelombang dan getaran. Sedangkan daerah yang termasuk elastis-plastis yakni Dusun Jeruk (R6, R9, R13, R14, R15, R19), Dusun Manggis (R7, R12, R30), Dusun Kemiriombo (R24, R25, R27), Dusun Srimulyo (R28, R31), Dusun Kalipak (R1), Dusun Petet (R3), dan Dusun Ngelebengan (R1011, R22) yang dapat terjadi berupa retakan dan penurunan tanah.

\subsection{Potensi tanah longsor menggunakan metode AHP}

Nilai hasil perhitungan pembobotan dengan metode statistik AHP dari semua parameter analisis maka diperoleh kategori potensi longsor dengan nilai $0,1310-0,1854$ untuk potensi rendah pada peta berwarna hijau, 0,1854-0,2397 untuk potensi sedang berwarna kuning dan 0,2397 - 0,2941 untuk potensi tinggi berwarna merah yang ditampilkan pada Gambar 7.

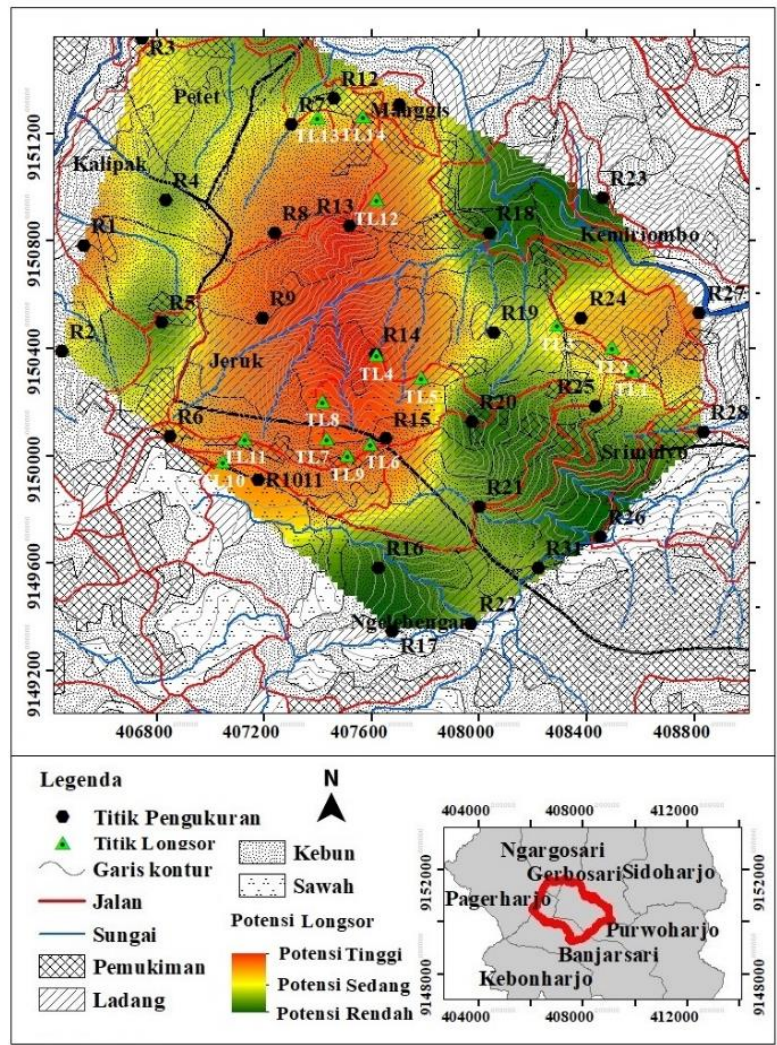

Gambar 10. Peta potensi longsor dan overlay titik kejadian longsor (segitiga hijau) berdasarkan perhitungan dengan metode AHP.

Pembagian kelas potensi longsor pada masingmasing dusun menunjukkan bahwa untuk Dusun Jeruk terdiri atas potensi rendah $(9,55 \%)$, potensi sedang $(9,98 \%)$ dan potensi tinggi $(14,32 \%)$, Dusun Manggis memiliki potensi sedang $(10,05 \%)$ dan potensi tinggi (3,30\%), Dusun Kemiriombo terdiri atas potensi rendah $(3,14 \%)$, potensi sedang $(5,18 \%)$ dan potensi tinggi $(3,46 \%)$, Dusun Srimulyo terdiri atas potensi rendah $(6,37 \%)$ dan potensi sedang $(3,28 \%)$, Dusun Kalipak terdiri atas potensi sedang $(4,61 \%)$ dan potensi tinggi $(3,46 \%)$, Dusun Pelet terdiri atas potensi rendah $(2,25 \%)$ dan potensi sedang $(3,31 \%)$, Dusun Ngelebengan terdiri atas potensi rendah $(6,39 \%)$ dan potensi tinggi $(3,44 \%)$. Berdasarkan presentase tersebut daerah yang mempunyai potensi longsor tertinggi berturut-turut adalah Dusun Jeruk, Dusun Ngelebengan, Dusun Kalipak, Dusun Kemiriombo dan Dusun Manggis. Adapun daerah yang tidak mempunyai potensi longsor tinggi adalah Dusun Srimulyo dan Dusun Pelet. mempunyai potensi longsor tertinggi berturut-turut adalah Dusun Jeruk, Dusun Ngelebengan, Dusun Kalipak, Dusun Kemiriombo dan Dusun Manggis. Adapun daerah yang tidak mempunyai potensi longsor tinggi adalah Dusun Srimulyo dan Dusun Pelet. 


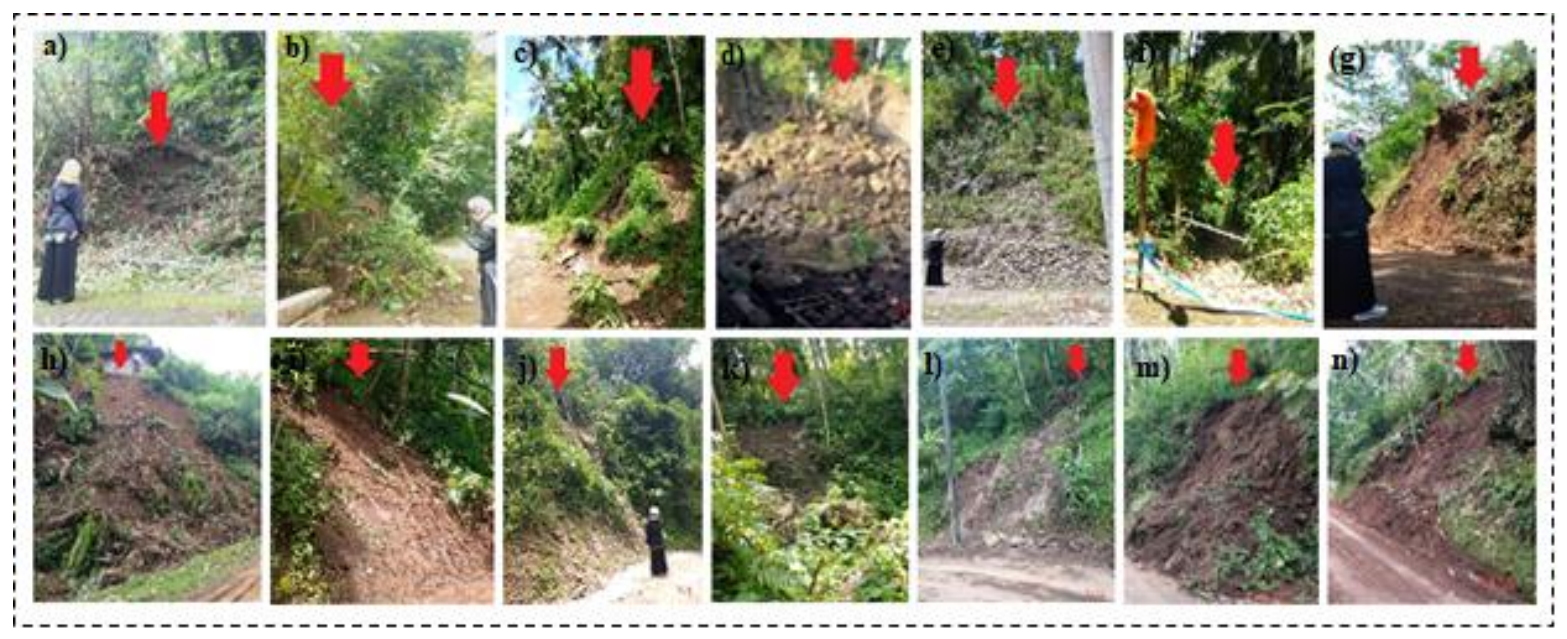

Gambar 11. Foto dokumen kejadian longsor sekitar daerah penelitian dan titik awal longsoran (panah merah). a) TL1, b) TL2, c) TL3, d) TL4, e) TL5, f) TL6, g) TL7, h) TL8, i) TL9, j) TL10, k) TL11, l) TL12, m) TL13, dan n) TL14.

Berdasarkan foto dokumen diperoleh 14 lokasi kejadian longsor di daerah penelitian yang ditampilkan pada Gambar 11. Kejadian longsor tersebut dijadikan sebagai validasi data lapangan dengan metode AHP yang telah dibuat dalam penelitian ini. Kejadian longsor pada 14 titik lokasi, sebanyak 11 titik lokasi berada pada daerah yang memiliki potensi tinggi dan 3 titik lokasi berada pada daerah yang memiliki potensi sedang. Hasil perhitungan ini menunjukkan bahwa tingkat validasi untuk daerah yang memiliki potensi tinggi dalam studi ini adalah 78,57 \%. Perhitungan validasi berdasarkan presentasi jumlah kejadian yang telah terjadi di daerah penelitian sebanyak 14 titik dengan hasil analisis yang berpotensi tinggi sebanyak 11 titik. Secara matematis dituliskan sebagai berikut.

$$
\frac{11}{14} \times 100 \%=78,57 \%
$$

\section{Kesimpulan}

Berdasarkan perhitungan dan pembobotan statistik Analytical Hierarchy Process nilai parameter analisis indeks kerentanan seismik (Kg), ketebalan lapisan sedimen, peak ground acceleration (PGA) dan ground shear strain (GSS), diperoleh bahwa nilai parameter yang dihasilkan tinggi di beberapa bagian daerah penelitian. Nilai tertinggi tersebut sebagian besar berada di daerah kecamatan samigaluh bagian selatan yang meliputi Dusun Jeruk, Dusun Ngelebengan, Dusun Kalipak, Dusun Kemiriombo dan Dusun Manggis dimana lokasi tersebut dilaporkan sering terjadi kejadian longsor [5]. Informasi ini diharapkan sebagai acuan data pemerintah dan warga setempat untuk dilakukan mitigasi pengurangan risiko bencana longsor terkhusus pada daerah kecamatan Samigaluh.

\section{Ucapan Terima Kasih}

Penulis mengucapkan terima kasih kepada BPBD Kecamatan Samigaluh atas diskusi kejadian longsor di wilayah penelitian dan pemberian fasilitas tempat tinggal, Departemen Fisika, FMIPA, UGM atas pemberian dana selama proses pengambilan data, serta Lab Geofisika FMIPA UGM atas peminjaman alat Seismometer lennertz le$3 d / 20 s$.

\section{Daftar Pustaka}

[1] Karnawati, D., The Mechanism of Rock Mass Movements As the Impact of Earthquake, Din. Tek. Sipil, 7(2), pp. 179-190, 2007.

[2] Kawasan Rawan Bencana (KRB) Kabupaten Kulon Progo, bpbd.kulonprogokab.go.id/detil /368/kawasan-rawan-bencanakabupatenkulon-progo (accessed 02 December 2020).

[3] Rahardjo,W., Rumidi S. and Rosidi H.M.D., Geological map of the Yogyakarta Quadrangle, Java, skala $1: 100.000$, Geological Survey of Indonesia, pp. 1-15, 1977.

[4] Rata-Rata Curah Hujan dan Hari Hujan Menurut Kecamatan Per Bulan di Kabupaten KulonProgo,https://kulonprogokab.bps.go.id (accessed 25 November 2019).

[5] Data laporan Bencana Kecamatan Samigaluh, https://samigaluh.kulonprogokab.go.id, (accessed 16 Agustus 2020).

[6] SESAME, Guidelines for the implementation of the $\mathrm{H} / \mathrm{V}$ spectral ratio technique on ambient 
vibrations. Measurements, processing, and interpretations. WP12 European commission Research general directorate project no. EVG1-CT-2000-0026 SESAME, http://sesame. geopsy.org/Papers/HV_User_Guidelines.pdf

[7] Nakamura, Y., Clear identification of fundamental idea of Nakamura's technique and its applications. In Proceedings of the 12th world conference on earthquake engineering, (2656), 2000.

[8] Secht, M.I, and Wohlenberg, J., Microtremor Measurements Used to Map Thickness of Soft Sediments," Bull. Seismol. Soc. Am., 89(1), pp. 250-259, 1999.
[9] Kanai, K., Improved Empirical Formula for Characteristics of Stray (Sic) Earthquake Motions. in Proceedings of the Japanese Earthquake Symposium, pp.1-4, 1966.

[10] Ratdomopurbo, A., dan Suharna., Pedoman Pemetaan Mikrozonasi, Badan Geologi, Dapertemen Energi dan Sumberdaya Mineral, 2008.

[11] M. Muzli, M., Masturyono, M., Murjaya, J., \& Riyadi, Studi Awal Penyusunan Skala Intemsitas Gempabumi, J. Meteorol. dan Geofis., 2(17), pp. 89-99, 2017.

[12] Ishihara, K., Soil Behaviour in Earthquake Geotechnics, Oxford University Press Inc, 1996. 